\title{
Fortidens fremtid
}

\section{- historien om scenekunstarkivet Sceneweb}

\author{
Elisabeth Leinslie
}

\begin{abstract}
Performing art is part of our national cultural heritage and in Norway we have good traditions for preserving the cultural heritage. For many years, however, performing arts was an art field where cultural heritage work was weak. During the last 10-15 years, this work has been strengthened. In this article, I will give an introduction to the work of a national digital performing arts archive that was developed during this period: Sceneweb - which is owned and operated by Performing Arts Hub Norway (PAHN). The Sceneweb database is a professional system adapted for the classification of performing art material. It is an object-based relational database which can function as an authority register and national standard for the recording of performing art material. In this article, I outline the choices that lie behind the development of this system, and for our national plan for the preservation and dissemination of archival material. I also explain our extensive cooperation with the National Library.
\end{abstract}

Keywords: kulturarv, arkiv, database, kunnskapsorganisering, autoritetsregister, metadata

\section{Om forfatteren}

Elisabeth Leinslie er redaktør for Sceneweb. Leinslie er teaterviter, skribent og lektor. Hun har vært ansatt i Danse- og teatersentrum (DTS) siden 2008. I DTS arbeider hun hovedsakelig som teaterviter, arkivar, skribent og redaktør for Sceneweb. Elisabeth Leinslie arbeider også som frilansskribent og anmelder.

\section{elisabethleinslie@gmail.com}

Teatervitenskapelige studier 2019 (C) Elisabeth Leinslie

Nummerredaktører: Anette Therese Pettersen og Elisabeth Leinslie

Medredaktør: Julie Rongved Amundsen. For TVS: Ragnhild Gjefsen

Ansvarlig redaktør: Tor Bastiansen Trolie - tor.trolie@,uib.no

Publisert av Teatervitenskap, Institutt for lingvistiske, litterære og estetiske studier, Universitetet i Bergen

Bergen Open Access Publishing - https://boap.uib.no/index.php/tvs

ISSN: 2535-7662

Manusutviklingen av disse artiklene er støttet av: Danse- og teatersentrum, Norsk Kulturråd, Kristiansand kommune, Fritt Ord, BIT teatergarasjen, Dramatikkens hus, Bergen kommune. 


\section{Fortidens fremtid}

\section{- historien om scenekunstarkivet Sceneweb}

Scenekunst er en del av vår nasjonale kulturarv, og i Norge har vi gode tradisjoner for å bevare kulturarven. Arbeidet med bevaring av norsk scenekunstarv gjøres i dag av museer, arkivinstitusjoner, biblioteker og scenekunsfeltets egne institusjoner og organisasjoner. Et slikt kulturarvarbeid innebærer at man velger ut hvilket dokumentasjonsmateriale som får overleve fra scenekunstfeltet, til generasjoner inn i fremtiden. Og en slik utvelgelse fordrer bevissthet om feltets historie, normer og verdier.

$\AA$ bevare scenekunstarven har betydning for dagens bruk og publikumsoppslutning, men den er grunnleggende viktig for vårt samfunnsminne, og dette arbeidet peker dermed fremover - inn $\mathrm{i}$ fremtiden.

Scenekunstsamlingene vi finner i Norge i dag er organisert på mange forskjellige måter og er i ulik grad tilgjengelige. Skal vi tenke oss et fremtidig norsk samfunn med god kunnskap om vår scenekunstarv, trenger vi, slik jeg ser det, gode og tilgjengelige arkiv. I denne artikkelen vil jeg se nærmere på arbeidet med ett av disse arkivene: det nasjonale digitale scenekunstarkivet Sceneweb.

\section{Danse- og teatersentrum og Sceneweb}

Stiftelsen Danse- og teatersentrum (DTS), som er et nasjonalt kompetansesenter for scenekunst, eier og drifter scenekunstarkivet Sceneweb. DTS startet arbeidet med ideen om å dokumentere og katalogføre norsk scenekunsthistorie i 2001. ${ }^{1}$ Dette ble først gjort ved å utvikle og drifte en repertoardatabase over deler av norsk fri scenekunst. Denne første repertoardatabasen til DTS inneholdt hovedsakelig produksjoner av stiftelsens medlemmer og produksjoner som ble tatt inn i repertoaret til Norsk Scenekunstbruk som på den tiden var en del av DTS' daglige drift. ${ }^{2}$

Våren 2007 videreutviklet DTS ideen om å dokumentere og katalogføre norsk scenekunsts historie ved å starte et omfattende kulturarvprosjekt. Prosjektet ble gitt navnet Sceneweb - et dokumentasjons-, informasjons- og databaseprosjekt. Stiftelsen dannet først en arbeidsgruppe bestående av nestleder i DTS Ådne Sekkelsten, bibliotekar (med spesialkompetanse på repertoardatabaser) Bjørge Vestli, teaterviter Elisabeth Leinslie, dokumentarfilmskaper John Sullivan og kritiker/journalist IdaLou Larsen. Arbeidsgruppen utviklet prosjektbeskrivelse og søknad til Kulturrådet. Prosjektet mottok til sammen treårig støtte fra Kulturrådet ${ }^{3}$. Bjørge Vestli ble ansatt det første året for å være med på utviklingen av databasen, og jeg, Elisabeth Leinslie, ble ansatt som prosjektleder.

Sceneweb skulle først og fremst være et digitalt arkiv for fri scenekunst i Norge, og arkivet skulle tilgjengeliggjøres på Internett. I tillegg skulle arkivet oversettes til engelsk. Etter flere måneder med research på eksisterende databaser og arkivmateriale, ble to viktige avgjørelser tatt: 1 - det var behov for å utvikle en ny database spesialtilpasset scenekunstmaterialer, 2 - det var behov for å samle hele scenekunstfeltet $\mathrm{i}$ ett arkiv, bare slik ville det være mulig å gi en god fremstilling av scenekunsten som ett kunsthistorisk felt. Dermed ble også de offentlige og private institusjonene 
innlemmet i dette arkivarbeidet. Dette førte til at arkivet ble vesentlig mer omfattende enn det vi tenkte i første runde.

Senhøstes 2008 startet Bjørge Vestli og jeg utviklingen av databasen samt nettsiden den skulle tilgjengeliggjøres på. Visjonen og formålet med arkivet ble samtidig formulert: «Formålet med Sceneweb er å dokumentere, arkivere og formidle norsk scenekunstarv, og med det stimulere bruken av arkiv- og informasjonsmateriale om norsk scenekunst.» «Scenewebs visjon er å skape et felles sted å gå til når man søker informasjon om norsk scenekunst, dens bransje i dag og dens historie.»

Den dagsaktuelle informasjonen var opprinnelig tenkt å ha stor betydning $\mathrm{i}$ arbeidet. Vi gjorde omfattende research på billettsystemer og muligheter for å skape en fullstendig nasjonal kalender over forestillinger. Denne delen av prosjektet lot seg ikke gjennomføre økonomisk uten støtte fra scenekunstfeltets egne institusjoner. Vi klarte dessverre ikke å samle feltet til å gå inn i et slikt felles kalender- og billettsystem, så etter flere år ble det tatt en avgjørelse på at Sceneweb kun skulle være et arkiv.

DTS valgte til slutt å utvikle en nasjonal plan for bevaring og formidling av arkiv fra bele det norske profesjonelle scenekunstfeltet. Stiftelsen tok med dette på seg en kulturarvvirksomhet som i perioder vokste den over hodet, men i et langtidsperspektiv har det vist seg å være et riktig valg. For bare ved å samle hele feltet kan brukere av arkivet få en helhetlig oversikt over dette kunstfeltet og kunstnerskapene som tilhører dette.

\section{Nasjonal plan for bevaring og formidling}

Siden oppstarten i 2008 var DTS i dialog med Nasjonalbiblioteket (NB) om arkivarbeidet. NB er en samlingsforvalter og et forskningsbibliotek, og har som mål i sin strategiplan at «Nasjonalbiblioteket skal være den fremste kilden til kunnskap om Norge og norske forhold. Ved å ta vare på kulturarven og det offentlige ordskiftet skal Nasjonalbiblioteket danne grunnlag for dokumentasjon, forskning og læring og bidra til å skape identitet og tilhørighet.» ${ }^{4}$ NB samler inn, digitaliserer, langtidsbevarer og tilgjengeliggjør publisert materiale innen alle typer medier. Virksomheten er forankret i Pliktavleveringsloven ${ }^{5}$, men tar også imot privatarkiv og en mengde upublisert materiale. Nasjonalbiblioteket er også ledende på digitalisering. Deres visjon om å digitalisere hele samlingen er godt på vei mot målet.

Da Scenewebdatabasen var ferdig utviklet i 2012, startet DTS og NB et pilotsamarbeid om innsamling, digitalisering, bevaring og tilgjengeliggjøring av scenekunstmateriale. 21 scenekunstorganisasjoner ble invitert til å bidra med innsending av materiale i forbindelse med dette pilotsamarbeidet. 20 takket ja, og inngikk samtykkeerklæring knyttet til materialet de leverte inn. Organisasjonene ble bedt om å levere inn plakater og forestillingsprogrammer, da dette var materialtyper NB hadde klare digitalsieringsløyper for på denne tiden. ${ }^{6} \mathrm{Da}$ NB fikk inn materialet ble det digitalisert. Både det fysiske og digitale materialet ble lagt i deres magasiner for langtidsbevaring, det ble tilgjengliggjort på NB sine hjemmesider som enkeltdokumenter og filene ble sendt til DTS. DTS organiserte det digitaliserte materialet i sitt fagsystem 
(Scenewebdatabsen), hvor det blant annet ble knyttet til riktig produksjon og copyrightholdere samt tilgjengeliggjort.

Illustrasjon: Eksempel på hvordan et forestillingsprogram er registrert og tilgjengliggiort. Øverst ser du hvordan Nasjonalbiblioteket formidler og hva de har registrert av metadata, under finner du samme forestillingsprogram i Sceneweb (eksemplet er programmet fra produksjonen Hundre hemmeligeter ved Trøndelag Teater i 2014).

$\leftarrow \rightarrow$ C Nasjonalbiblioteket [NO] https://www.nb.no/items/e509d26baf28f2434949e99bbb929db2?page=0\&searchText=Equus\%20trøndelag\%20teater 放

$\leftarrow$ Tilbake til trefflisten

Hundre hemmeligheter : av Anne Marit Sæther, Cirka teater og Eirik Hegdal

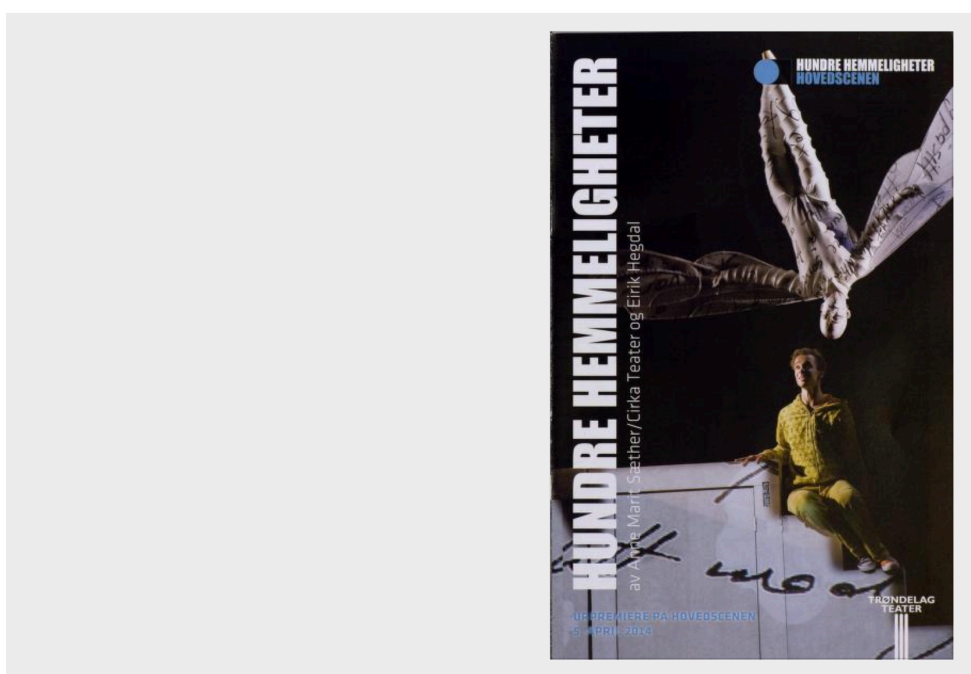

। Neste treff $\rightarrow$

目: $=Q \quad[\quad<\star \pm$

(i) sceneweb.no/nb/multimedia/68571

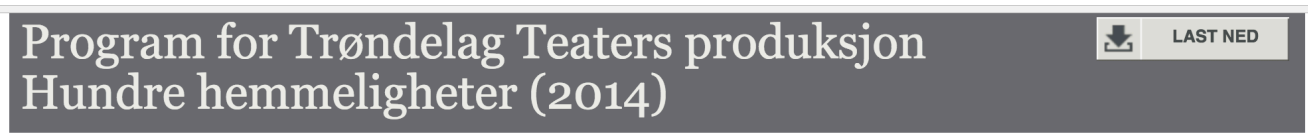

\begin{tabular}{ll} 
Publiseringsdato & 5. apr 2014 \\
\hline Digitaliseringsdato & 2015 \\
\hline Aksesjonsdato & 28. nov 2016 \\
\hline Kategori & Tekst / Program \\
\hline Lisens & @ Trendelag Teater \\
\hline Farger & Farge \\
\hline Lengde & 8 sider \\
\hline Bunnmateriale & Papir \\
\hline Illustrasjon & Illustrert \\
\hline Emneord & Program, Teater, Barn og unge \\
\hline Språk & Bokmål \\
\hline Tilknyttet & \\
\hline
\end{tabular}

- Nasjonalbiblioteket (Organisasjon) - Forvalter

- Trøndelag Teater (Organisasjon) - Produsent, Opphavsperson, Utgiver

\section{Filen vises på}

- Hundre hemmeligheter (Trøndelag Teater) (Produksjon)

- Nasjonalbiblioteket (Organisasjon)

- Trøndelag Teater (Organisasjon)
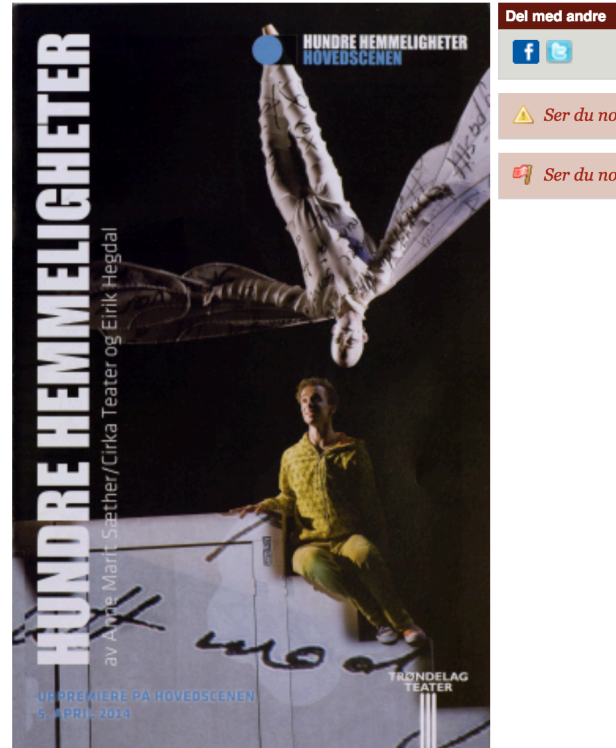

$f(3)$

Mer om Program for Trøndelag Teaters produksjon Hundre hemmeligheter (2014)

Program for Trondelag Teaters produksjon Hundre hemmeligheter (2014).

Pilotsamarbeidet med Nasjonalbiblioteket ble etter ett år utvidet til et langsiktig samarbeid med en uttømmende visjon: «Sammen ønsker vi å bidra til at norsk scenekunst i sin fulle bredde blir 
dokumentert, bevart og tilgjengeliggjort til glede for dagens og fremtidens publikum, forskere og allmennhet.» ${ }^{7} \mathrm{Med}$ andre ord: Alle profesjonelle scenekunstaktører i Norge inviteres nå til å levere inn materiale, slik at det kan bevares, digitaliseres og tilgjengeliggjøres. Samarbeidet er i senere tid utvidet til en materialtype til; festival- og sesongprogrammer. Vi har sammen arrangert to konferanser om teaterarkiv: A samle scenekunst, med fokus på innsamling, digitalisering og bevaring av teatermateriale (i Mo i Rana i 2016) ${ }^{8}$, og A åpne scenekunstens fortid, med fokus på formidling og bruk av arkivene (i Oslo i 2018).

\section{Arkiv og utvelgelse}

Det finnes fire grunnleggende søyler i det klassiske arkivet: lagring, bevaring, klassifisering og tilgjengelighet. ${ }^{9}$ Disse søylene er også gjeldende i et digitalt arkivsystem. Lagring og bevaring omhandler hvordan man tar vare på arkivmateriale, slik at det blir minst mulig utsatt for slitasje. Klassifisering handler om hvordan man ordner materialet og produserer metadata, og til slutt tilgjengeliggjøring som handler om hvordan man gjør arkivmaterialet tilgjengelig for brukerne.

Når man skal skape et arkiv, må man gjøre avgrensninger. Man må velge hvilke materiale som skal inkluderes i arkivet, og hva som skal velges bort. I dette arbeidet ligger det mye ansvar da valgene man tar er på vegne av en eller flere grupper i samfunnet. I denne utvelgelsesprosessen ligger det mye makt, makt over hva som velges for å bli husket i fremtiden. Deri også makt til å definere historien. Ofte er det nettopp slik at arkivenes innhold definerer historien, og hvor ofte har ikke viktig kildemateriale blitt destruert av myndigheter eller andre med makt (også eiere av privatarkiv), slik at folket ikke skal bli kjent med den egentlige og sanne historien?

En scenekunstsamling er som oftest et hybridarkiv fordi det finnes en rekke forskjellige materialtyper knyttet til et verk: fotografier, plakater, programmer, magasiner, artikler, anmeldelser, skisser, kostymer, scenografimodeller, lydfiler, tekst/manus, noter og videoer.

Samlingene kan komme i mange former. En samling kan for eksempel være tre pappesker med uordnet materiale, eller fem permer med ordnet materiale, eller det kan være et teaters repertoarhistorikk, enten på papir, et excel-ark, et word-dokument, en pdf-fil, en samling forestillingsprogrammer eller også som en repertoardatabase. Bare de færreste teatrene har komplette repertoaroversikter. ${ }^{10}$ Som oftest setter vi som arbeider med Scenewebarkivet, repertoarhistorikken sammen ved hjelp av flere kilder. En scenekunstsamling består oftest av en blanding av materialer, og vi får dem i hus på ulike måter og ofte stykkevis og delt.

Da innholdet i Scenewebdatabasen skulle defineres, var det, som nevnt tidligere, to sentrale parametere: 1) profesjonell scenekunst og 2) den frie scenekunsten. Det var denne delen av det profesjonelle scenekunstfeltet (den frie scenekunsten) som på den tiden stod i størst fare for å bli glemt, mente vi. Bekymringen for sikkerheten rundt arkivene til de frie scenekunstnerne var stor. Faren for at disse skulle ende opp som evige skyggearkiver ${ }^{11}$, som ikke var tilgjengelige og etter hvert tapte, var overhengende i 2008. Bortsett fra disse to parameterne var det ønskelig å sikre så mye materiale som mulig: forestillingsprogrammer, plakater, fotografier, videoer, korrespondanse, anmeldelser, artikler, essays, spilleplaner, rapporter og lignende. 
Vi erfarte imidlertid at fokuset på kun den frie scenekunsten ble for snevert, teater- og dansehistorisk sett, og at de fleste kunstnere beveger seg på tvers av den frie scenekunsten og offentlige og private institusjoner. For å kunne bevare historiene om kunstnerskapene, var det kun én løsning som var tilfredsstillende: å fokusere på hele scenekunstfeltet. Ganske snart ble derfor første parameter forandret til å inkludere scenekunst fra både offentlige og private institusjoner. Teaterfaglig sett var dette nødvendig for å speile den riktige scenekunsthistorien. Det viste seg videre at flere institusjoner hadde lite fokus på sine egne arkiv, i denne delen av feltet var det mange og store skyggearkiver. Flere arkiv var også lagret på en ytterst usikker måte. Spesielt utbredt var det at fysiske institusjonsarkiv var plassert i vanlige kontorlokaler uten brannsikring.

Skyggearkivene blir først et problem når materialet mangler. De fleste kompanier og kunstnere oppbevarer sine arkiver i esker og permer på loft eller i kjellere i sine privatboliger. Brann og fuktighet kan lett ødelegge disse arkivene. For eksempel mistet Samovarteatret i Kirkenes hele sitt arkiv i 2005 da deres lokaler brant ned. Som nevnt over, er dette problemstillinger vi også møter i de større institusjonene. I løpet av de ti årene DTS har arbeidet med arkiv, har vi fått flere skyggearkiv frem i lyset: privatarkivene til Helge Reistad, Baktruppen, Elsa Kvamme, Perleporten Teatergruppe, flere av institusjonenes repertoarhistorikk, programmer, plakater og fotografier. Flere fysiske arkiv er også levert til Nasjonalbiblioteket for langtidsbevaring, blant annet arkivene til Helge Reistad, Baktruppen, Tramteatret og Oslo Nye Teater.

\section{Digital vending $i$ arkivene}

I 2008 var digitaliseringen av samlinger fra flere felt i full gang over hele landet. Digitalisering var et buzz-ord, og store midler ble bevilget til dette arbeidet. Innen arkiv- og biblioteksektoren så man for seg digitalisering som en sentral metode for å sikre Norges kulturarv for fremtiden, og for bruk i samtid og fremtid. Dette ble ansett som morgendagens informasjons- og kunnskapshåndtering. ${ }^{12}$

Fokuset på betydningen av digitalisering har vedvart. Professor i medievitenskap ved Universitetet i Oslo og SIFO, Terje Rasmussen, påpeker at noen går så langt som å hevde at informasjon fremstår best i digital form, fordi de mener den er mer brukervennlig, relevant, effektiv og fleksibel enn i fysisk form. ${ }^{13}$ Arkivverkets erfaring viser også at mer digitalisering og tilgjengelighet gir mer bruk. ${ }^{14}$

Sceneweb var fra starten av tenkt som et digitalt arkiv av flere årsaker: 1) DTS ønsket et arkivsystem som kunne hjelpe til med å skape sammenheng i det mangfoldige kunnskapsuniverset vi stod overfor, og da var en form for objektbasert og relasjonell database den beste løsningen. 2) DTS ønsket å skape et arkiv som var lett tilgjengelig for alle, og da var et system som kunne publiseres på Internett den beste løsningen. 3) DTS var fra starten i dialog med NB om et mulig samarbeid. På grunn av positiv interesse fra NB rundt arbeidet med Scenewebdatabasen allerede i oppstartsfasen, valgte vi å ikke investere i egnede lokaler og kompetanse til å bevare det fysiske materialet. 
Vi i DTS anser det som svært viktig at scenekunstarven er en del av samfunnets offentlige informasjonsstruktur. Skal kulturarven være relevant for publikum, bør den være lett tilgjengelig og gjenfinnbar. I den enorme mengden digital informasjon vi finner på Internett, er det imidlertid lett å gå seg vill. Det er derfor sentralt å skape gode systemer for organisering av materialet $\mathrm{i}$ samlingene, gode systemer som hjelper brukeren $\mathrm{i}$ å gjenfinne riktig materiale.

\section{Databasen som verktøy for kunnskapsorganisering}

Så lenge mennesket kan huske har vi forsøkt å organisere våre eiendeler, kunnskap og samlinger. Om det var antikkens greske mor som organiserte spisskammerset sitt, eller munken som hadde lært seg skriftspråket og skrev alt ned, for slik å bygge opp et bibliotek. Eller Linné som ordnet planteriket i et system, eller Dewey som skapte et system for klassifisering av litteratur. Når vi beveger oss inn i den digitale tidsalderen, finner vi en rekke arkiv- og biblioteksystemer som er etablert som standarder for organisering av forskjellige former for materiale, for eksempel MARC, CIDOC CRM, FRBR og Primus. ${ }^{15}$

Kunnskapsorganisering kan, ifølge den danske bibliotekprofessoren Birger Hjørland, forstås i både snever og bred forstand. I bred forstand er kunnskapsorganisering en aktivitet eller prinsipper som ordner alle typer kunnskap. I snever forstand er kunnskapsorganisering en aktivitet eller prinsipper for organisering av metadata-representasjoner av kunnskapsbærere. Metadatarepresentasjon er de «elementene kunnskapsorganisatoren velger ut for å representere det dokumentet som er den faktiske kunnskapsbæreren (og her må et dokument forstås i videste betydning, brukt om all representert kunnskap, i form av tekst, lyd, bilde)..» ${ }^{16}$

I International Encyclopedia of Information and Library Science defineres kunnskapsorganisasjon slik:

$[\ldots]$ the description of documents, their contents, features and purposes, and the organization of these descriptions so as to make these documents and their parts accessible to persons seeking them or the message they contain. Knowledge organization encompasses every type and method of indexing, abstracting, cataloguing, classification, records management, bibliography and creation of textual or bibliographic databases for information retrieval.

Definisjonen understreker at kunnskapsorganisasjon dreier seg om to hovedaktiviteter: selve beskrivelsen av dokumentene og ordningen av disse dokumentene. Definisjonen viser ogsa at organiseringen har som formal at dokumentene, og kunnskapsinnholdet i og om dem, skal tilgjengeliggjøres, slik at publikum kan finne dem. Slik sett peker definisjonen på to sentrale aktiviteter: 1) selve kunnskapsorganiseringen, det vil si kunnskapsorganisatorens arbeid med organisering og produksjon av metadata knyttet til dokumenter og disses potensial som kunnskapskilder, 2) publikums arbeid med informasjonsgjenfinning. ${ }^{17}$

Når man arbeider med kunnskapsorganisasjon, er klassifisering en sentral aktivitet. Klassifisering er en måte å organisere store samlinger på - systematisk og etter prinsipper som ordner hvert element entydig, slik at det skiller seg fra andre elementer i samlingen, som for eksempel å skille fotografier fra plakater. ${ }^{18}$ Samlingene knyttet til scenekunst er, som nevnt, hybridarkiver i den 
forstand at det finnes en rekke forskjellige materialtyper knyttet til ett verk, samtidig er scenekunst en tids- og hendelsesbasert tverrestetisk kunstform. Disse parameterne krever et spesielt tilpasset system for organisering av materialet.

I 2008 var ikke klassifisering av scenekunst et felt som var utviklet innen arkiv- og biblioteksektoren. Derfor endte vi opp med å utvikle egne prinsipper og standarder basert på flere foreliggende systemer. Vårt mål var at Scenewebdatabasen skulle bli et spesialtilpasset system, utviklet i henhold til scenekunstens særpreg som kunstform og de materialtypene som finnes i scenekunstsamlingene. Først og fremst ble nasjonale standarder for blant annet fotomateriale, litteratur, personer, korporasjoner, geografiske steder, billedmateriale, video og film undersøkt. Disse standardene følges i Scenewebdatabasen.

Etter omfattende gjennomgang av flere repertoardatabaser og databaser fra andre kunstfelt endte vi opp med å konstruere databasen rundt sju hovedkategorier: organisasjon, produksjon, person, spillested, originalverk, utmerkelse og multimedia. Hovedkategoriene inneholder flere underkategorier, for eksempel vil man i hovedkategorien multimedia (som er samlekategorien for alle digitale filer) finne underkategoriene levende bilde, lyd, stillbilde og tekst. Underkategoriene er igjen delt inn i flere underkategorier: for eksempel under stillbilde finner vi delkategoriene bildeserie, digitalt design, fotografi, grafikk, maleri, plakat, scenografi, skisse og tegning.

Vi oppdaget raskt at de elementene vi hadde med å gjøre, i liten grad lot seg ordne hierarkisk. For hva er viktigst: Organisasjonen Nationaltheatret, personen Henrik Ibsen eller urfremførelsen av Ibsens skuespill Hedda Gabler? - Ole Bull eller Det Norske Theater? Dette ble umulige problemstillinger, og valget falt derfor på å skape en objektbasert database hvor objektene er likestilte. Videre ønsket vi at hovedkategoriene skulle kunne bindes sammen i et relasjonelt system som i et rhizom, hvor alt henger sammen i et demokratisk nettverk. Relasjonsmodellen har etter hvert vokst frem som en standard for databaser. ${ }^{19}$ Ved hjelp av denne databasemodellen kunne man for eksempel organisere alt materiale om en produksjon, både hver for seg $o g$ binde det sammen for å vise konteksten, og dermed gi materialet/dokumentene en ytterligere informasjonsverdi. Vi ville med dette også få et spill mellom fortid og fremtid, ved at brukeren kunne få informasjon om alle oppsetninger av et manus i Norge gjennom tidene. Slik så vi for oss at publikum kunne møte fortidens scenekunst $\mathrm{i}$ all dens heterogenitet - samlet på ett sted. 


\section{Peer Gynt}

\begin{tabular}{ll} 
Originaltittel & Peer Gynt \\
\hline Verktype & Manus \\
\hline Publiseringsdato & 1867 \\
\hline Språk & Bokmål \\
\hline Originalspråk & Bokmål \\
\hline Kategorier & Drama \\
\hline Opphavsperson & \\
\hline
\end{tabular}

- Henrik Ibsen, Forfatter

Produksjoner

- Peer Gynt (2018 - Det Norske Teatret)

- Peer Gynt (2017 - Peer Gynt AS)

- Solveigs andre sang (2017 - Teater Innlandet)

- Peer, du lyver! (2015 - Riksteatret)

- Peer Gynt (2014 - Den Norske Opera \& Ballett)

- Peer Gynt (2014 - Nationaltheatret)

Vis alle
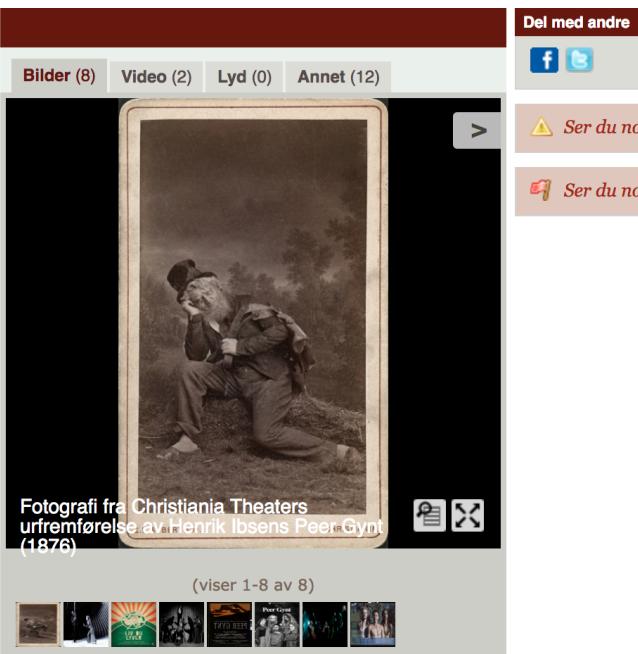

Peer Gynt (1867) er et dramatisk dikt/skuespill av Henrik Ibsen, som opprinnelig mente teksten som et lesedrama. Han tok senere

initiativ til å få det satt opp.

Peer Gynt ble uroppført som skuespill på Christiania Theater i Christiania (nå Oslo) 24. februar 1876, med musikk av Edvard Grieg. Les mer om uffremførelsen her.

Illustrasjon: screenshot av fremstillingen av et manus på sceneweb.no, her: skuespillet Peer Gynt av Henrik Ibsen.

\section{Autoritetsregister og nasjonal standard}

Hvert objekt i Scenewebdatabasen får et ID-nummer som skiller dem fra hverandre, slik at databasen kan fungere som et autoritetsregister for scenekunst. Autoritetsdata brukes innenfor bibliotek- og informasjonsvitenskap for å beskrive, identifisere og sammenstille poster om personer, steder, organisasjoner og åndsverk. Dataene er typisk en dataoppføring, eller et lite utvalg av identifiserende metadata, eller metadata som til sammen gir en høy sannsynlighet for korrekt identifisering eller sammenstilling. Brukere av slike data og metoder er arkiver, biblioteker og museer, men de kan brukes i enhver sammenheng hvor navngitte entiteter skal kobles opp mot poster i et datasett. ${ }^{20}$

Autoritetsregistre for personer, korporasjoner, geografiske steder og flere dokumenttyper finner vi i andre biblioteks- og arkivsystemer. Det var en type entitet/objekt vi ikke fant noe allerede eksisterende autoritetsregister for: Produksjoner - som innen scenekunst er selve kunstverket. Spesielt viktig ble derfor fokuset på å utvikle et autoritetsregister for produksjoner.

Vi utviklet også tilpassede standarder for registrering av digitalisert materiale. Standarder består av klassifikasjonstermer og emneord som benyttes til å gi fagspesifikk kunnskap om innholdet. Vi skapte altså standarder for termer og vokabular for tekstfelt og beskrivelser av dokumenter/objekter. Slik utviklet vi en fagspesifikk tesaurus for kunnskapsorganisatorene å arbeide utfra når de skal produsere metadata i Scenewebdatabasen. 


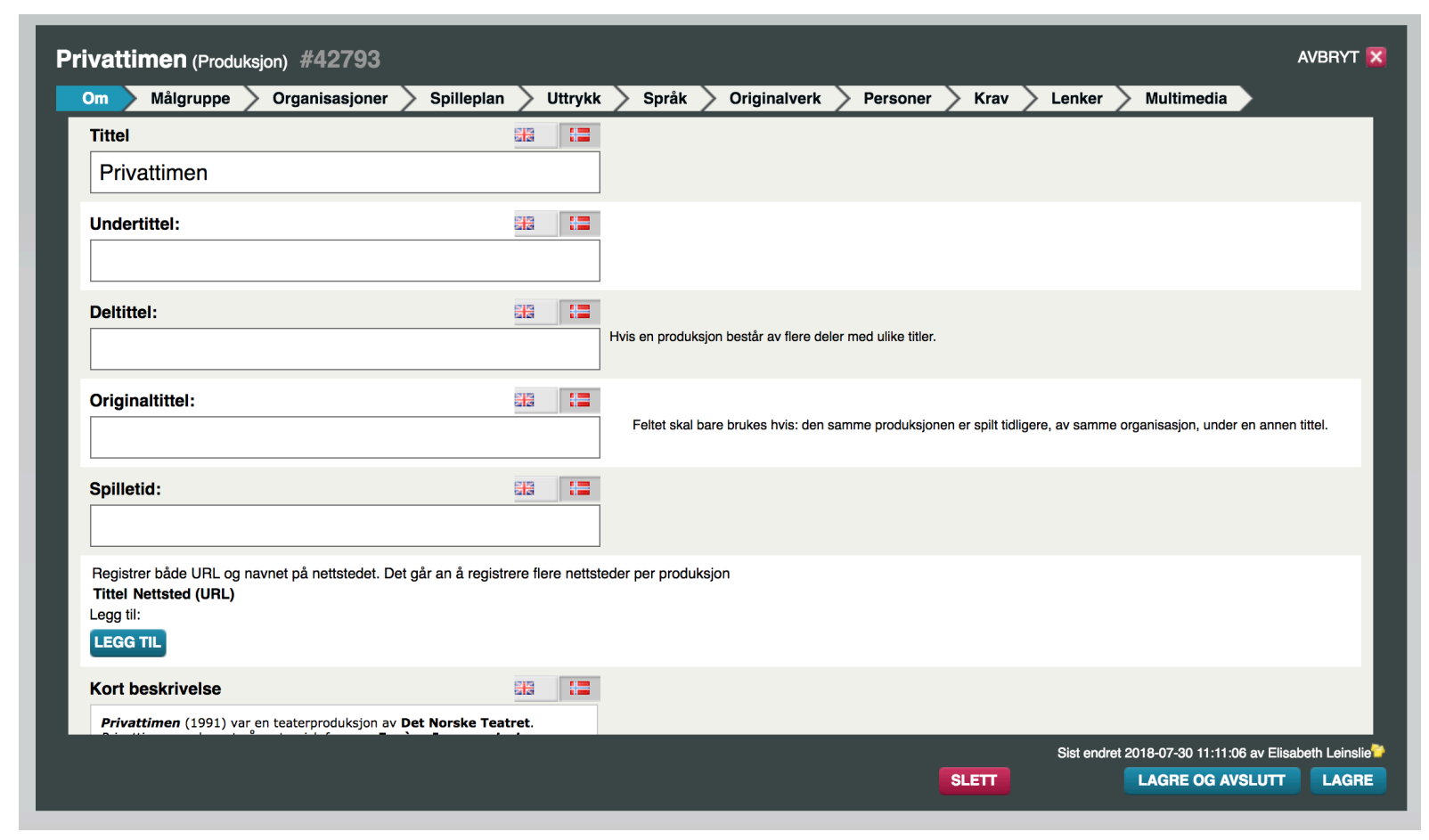

Illustrasjon: utdrag fra hvordan en produksjon reigstreres i backend i Scenewebdatabasen. Her; Privattimen av Det Norske Teatret i 1991.

Strukturerte metadata er helt sentralt når man arbeider med arkiv. Metadata skal beskrive innholdet, slik at det skilles fra annet innhold og enkelt kan gjenfinnes. I tillegg til å beskrive innholdet/dokumentet må metadataene også inkludere informasjon om hvordan materialet forholder seg til annet innhold i databasen, slik at brukerne lett kan navigere mellom relevante personer, organisasjoner, produksjoner, steder, emner og dokumenttyper. Metadataene skal også gi informasjon om hvilke personer eller organisasjoner som er intellektuelt og praktisk ansvarlig for materialet (forfatter, utgiver, oversetter, fotograf, lisensholder, eier, forvalter o.l.). ${ }^{21}$

Scenewebdatabasen er altså en objektbasert relasjonell database som nå er etablert som nasjonal standard for arkivering og ordning av scenekunstarkiv. Databasen er med andre ord spesialtilpasset scenekunstens hybridarkiv. Her kan mange ulike materialtyper katalogiseres og linkes sammen. Slik kan video, foto, plakat, artikkel og lignende fra en produksjon presenteres sammen med metadata om selve produksjonen. Et godt eksempel på hvor mange forskjellige materialtyper som kan være med å dokumentere en produksjon er Germania Tod in Berlin (1989) av Baktruppen http://sceneweb.no/nb/production/10302/Germania Tod in Berlin-1989-4-15. 


\section{Germania Tod in Berlin - Det tapte kjønn}

\begin{tabular}{ll} 
Premiere & 15. apr 1989 \\
\hline Produsert av & Baktruppen \\
\hline Coprodusenter & $\begin{array}{l}\text { BIT Teatergarasjen, Henie Onstad } \\
\text { Kunstsenter }\end{array}$ \\
\hline Basert på & Germania Tod in Berlin av Heiner Müller \\
\hline Målgruppe & Voksne, Ungdom \\
\hline Antall hendelser & 35 \\
\hline Språk & Norsk og Engelsk \\
\hline Uttrykksformer & $\begin{array}{l}\text { Performance, Teater, Tverrkunstnerisk, } \\
\text { Foredrag }\end{array}$ \\
\hline Spilleperiode & 15. apr 1989 - 14. des 1992 \\
\hline Spilletid & 40 min \\
\hline Nettsted & BAKTRUPPEN \\
\hline
\end{tabular}

Om Germania Tod in Berlin

Germania Tod in Berlin (1989) var en teaterproduksjon av

Baktruppen. Germania Tod in Berlirvar basert på Heiner Müllers dramatiske tekst med samme tittel. Germania Tod in Berlin ble produsen

i forbindelse med utstillingen Fotografi - 150 år på Henie Onstad

Kunstsenter i 1989. Produksjonen hadde premiere på Henie Onstad

Kunstsenter.

Baktruppen gjorde sitt internasjonale gjennombrudd med Germania Tod

in Berlin.

Les mer

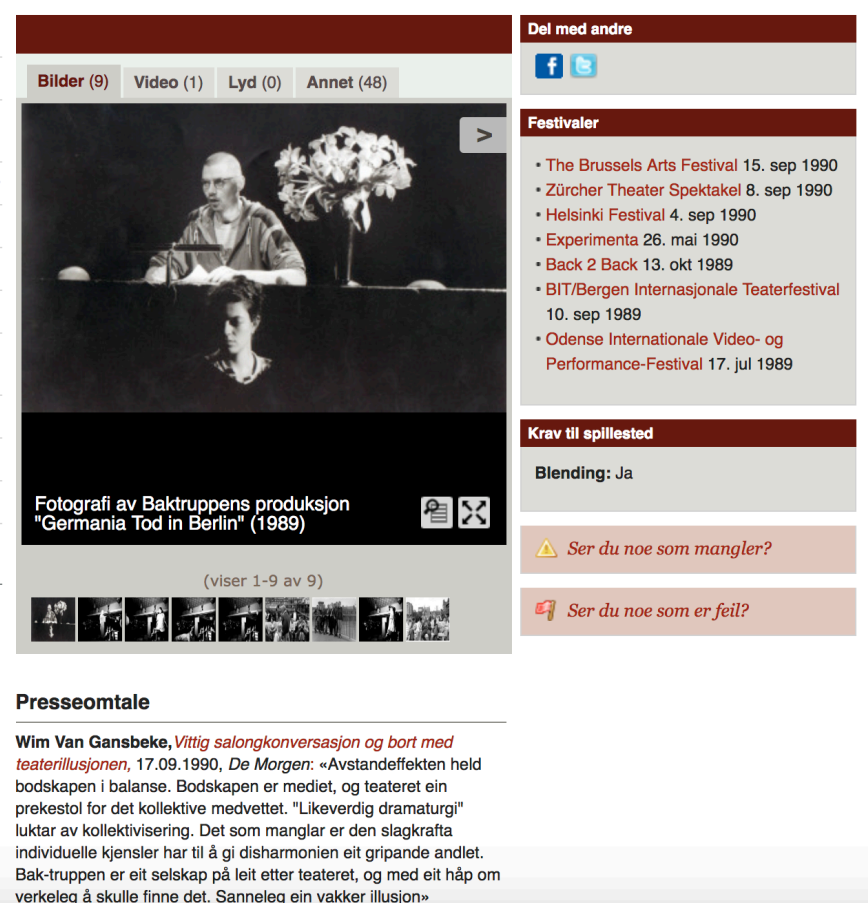

Illustrasjon: screenshot av fremstillingen av produksjonen Germania Tod in Berlin av Baktruppen på sceneweb.no (illustrasjonen viser deler av fremstillingen, gå til

http://sceneweb.no/nb/production/10302/Germania Tod in Berlin-1989-4-15 for å se fullstendig fremstilling).

\section{Tilgjengeliggjøring og gjenfinnbarhet}

For oss i DTS er det et viktig formål å tilgjengeliggjøre Scenewebdatabasen på Internett, også på engelsk, for å åpne databasen for alle brukere. Vi anser denne formen for tilgjengeliggjøring av samlingene som sentral for kunnskapsøkning og -produksjon. Dessuten er fanen om 'tilgjengelighet for alle' sentral i demokratiseringstanken rundt Scenewebdatabasen. Alle skal få tilgang til arkivmaterialet, og med dagens teknologi åpner det seg mange muligheter for hvordan å forenkle brukerens tilgang.

I dag er Internett vår mest sentrale kunnskapsallmenning. ${ }^{22}$ På Internett integreres skriftlig, muntlig og audiovisuell informasjon i et uavgrenset nettverk (gjennom hypertekstfunksjonen) som man kan navigere seg i på kryss og tvers. Potensialet for at man kan se sammenhenger fremfor bare begivenheter er stor. Det er også potensiale for å gå seg vill. ${ }^{23}$ Skal vi sikre oss at brukerne som leter etter informasjon om norsk scenekunst skal finne relevant informasjon, lener vi oss på strukturerte metadata som det kraftigste verktøyet.

Vi kommer igjen tilbake til viktigheten av kunnskapsorganisatorens arbeid og databasens struktur. Men enda et perspektiv er sentralt når vi snakker om tilgjengelighet og gjenfinnbarhet; det involverer utviklingen av et grensesnitt hvor formidling av kunnskap finner sted. Valg av grensesnitt påvirker i stor grad hvordan materialet i databasen presenteres og hvordan brukerne finner materialet. Her har hvert arkiv sine egne logikker, og brukere må gjøre seg kjent med de 
forskjellige (Internett)stedene individuelt for å kunne få mest mulig ut av dem.

Da Scenewebdatabasen (oktober 2012) ble tilgjengelig på Internett, ble en mengde materiale som tidligere hadde vært bortgjemt og vanskelig å få tilgang til, tilgjengelig for hele verden - bare et tastetrykk unna. ${ }^{24}$ Siden den gang har arkivets innhold økt betraktelig, og nytt materiale registreres fremdeles hver eneste dag. Arbeidet med Scenewebarkivet er et evighetsarbeid. Stadig finner vi arkivmateriale av eldre dato, og hver dag produseres det ny scenekunst som potensielt kan bli en del av arkivet. Slik sett strekker dette arkivarbeidet seg inn i fremtiden - i uoverskuelig tid.

\section{Arkiv for fremtiden}

Arbeidet med Scenewebarkivet er et arbeid som påvirker samfunnets kollektive hukommelse om norsk scenekunst - det er med på å definere norsk scenekunsthistorie for fremtiden. Når arkivmateriale blir lett tilgjengelig på denne måten, får det med andre ord konsekvenser for kunnskap som sådan. Akkurat hvilke konsekvenser kan være vanskelig å øyne, og kanskje vil ikke disse vise seg før en gang i fremtiden.

I og med at arkivet, i en viss grad, definerer historien for fremtiden, mener vi at Scenewebarkivet er til like mye for fremtiden som for nåtiden og fortiden. I dette perspektivet kan vi støtte oss på Jaques Derrida og hans 'economy of memory' ${ }^{25}$. I denne økonomien ligger både fortiden og fremtiden samtidig. Derrida skriver at det er vanlig å tenke at arkiv først og fremst peker mot fortiden, og at det er tro mot tradisjoner. Dette er det lett å si seg enig i. Derrida mener imidlertid at arkiv forst og fremst bør problematisere fremtiden:

And the word and the notion of the archive seem at first, admittedly, to point toward the past, to refer to signs of consigned memory, to recall faithfulness to tradition. If we have attempted to underline the past in these questions from the outset, it is also to indicate the direction of another problematic. As much as and more than a thing of the past, before such a thing, the archive should call into question the coming of the future. [...] It is a question of the future, the question of the future itself, the question of response, of a promise and of a responsibility for tomorrow. The archive: if we want to know what that will have meant, we will only know in times to come, later on or perhaps never. ${ }^{26}$

Som Derrida her beskriver: Når man arbeider med arkiv, har man fremtiden og fortiden i bevisstheten samtidig. En arkivar samler inn materiale fra fortiden, men må vurdere hva som er bevaringsverdig for fremtiden, og da må han/hun spørre seg hva som er viktig å vite om fortiden i fremtiden.

Da vi startet arbeidet med Sceneweb i 2008, var disse spørsmålene langt fremme i vår bevissthet. Både angående utviklingen av et digitalt arkivsystem som skulle vare i mange år hvilket materiale som skulle samles inn. Erfaringene på den tiden var at den offentlige bevisstheten om scenekunst ofte var begrenset til dagens repertoar eller knyttet til enkeltkunstnere, ofte kjendiser. Vi ønsket å gi fremtidens allmennhet en bredere tilgang til kunnskap om dette kunstfeltet, og skulle vi tenke fremtiden inn i scenekunstarkivene på denne måten, var inkludering av hele det profesjonelle 
scenekunstfeltet, en objektbasert relasjonell database og en tilgjengeliggjøring på Internett, de beste løsningene, slik vi vurderte det.

Vi ønsket også å øke bevisstheten om betydningen av egne arkiv hos scenekunstaktørene. Her har vi sett en positiv utvikling på flere måter: Mange aktører leverer inn materiale til Nasjonalbiblioteket og DTS/Sceneweb for digitalisering, bevaring og tilgjengeliggjøring. Flere institusjoner som ikke har kapasitet til å ta vare på egne fysiske arkiv, har avlevert disse i sin helhet til Nasjonalbiblioteket. Flere privatarkiv er blitt levert til DTS/Sceneweb og Nasjonalbiblioteket for digitalisering, bevaring og tilgjengeliggjøring. De fleste aktører har generelt mer fokus, og er bedre på dokumentasjon av egen virksomhet. Kunstnernes økte forståelse av seg selv som en del av kulturarven, er noe av det viktigste som har skjedd knyttet til arbeidet med Scenewebarkivet. For om man identifiserer seg som en del av en kulturarv, vil man også lettere forstå viktigheten av å bevare denne arven for fremtiden 


\title{
Noter
}

\begin{abstract}
${ }^{1}$ Man kan hevde at dokumentasjonsarbeidet startet enda tidligere: Da Danse- og teatersentrum ble etablert som Teatersentrum i 1977, startet de arbeidet med kataloger over de frie gruppenes produksjon. Hovedhensikten med disse katalogene var salg av forestillinger, men fungerer i dag som dokumentasjon over mange av gruppenes produksjoner. Katalogene ble produsert for årene 1978-2000. Katalogene er digitalisert og tilgjengeliggjort på Sceneweb. Se f.eks den første fra 1978:

http://sceneweb.no/nb/multimedia/36550. Norsk Scenekunstbruk ble skilt ut som et eget AS i november 2008.
\end{abstract}

${ }^{2}$ Norsk Scenekunstbruk ble skilt ut av DTS'daglige drift i 2008 og etablert som AS i 2009. DTS eier Norsk Scenekunsbruk AS.

${ }^{3}$ Høsten 2007 ble det gitt tildeling for to år, for utvikling av database og nettside, samt til innsamling, digitalisering og registrering av arkivmateriale. Våren 2008 ble det gitt støtte til ett tredje år, til arbeidet med innsamling, digitalisering og registrering av arkivmateriale.

${ }^{4}$ Nasjonalbiblioteket, nb.no, 21.01.2019, https://www.nb.no/om-nb/mandat-og-strategi/

${ }^{5}$ Nasjonalbiblioteket, nb.no, 21.01.2019, https://www.nb.no/pliktavlevering/

${ }^{6}$ I arbeidet knyttet til Pliktavleveringsloven arbeider NB metodisk med materialtyper. De utvikler egne systemer for innsamling, bevaring, registrering, digitalisering og tilgjengeliggjøring for hver enkelt materialtype. Etter at NB startet satsingen på digitalisering, har de utviklet metoder for håndtering av digitalisering av store mengder forskjellige materialtyper. Det er dette som kalles digitaliseringsløyper. En digitaliseringsløype tar for seg alle ledd i prossessen: innsamling, registrering, digitalisering, bevaring og tilgjengeliggjøring.

${ }^{7}$ Sitat fra informasjonsbrev om arkivsamarbeidet mellom Nasjonalbibliteket og DTS. Informasjonsbrevet blir sendt til organisasjoner/kunstere i scenekunstfeltet.

${ }^{8}$ Dokumentasjon fra konferansen $A$ samle scenekunst finner du på Sceneweb; 29.05.2019. https://sceneweb.no/nb/production/53561/\%C3\%85 samle scenekunst-2016-2-9

${ }_{9}^{9}$ Røssak, Archives in motion. Nota Bene.

${ }^{10}$ Så vidt vi vet, er det følgende teatre i Norge som har komplett repertoarhistorikk pr. d.d.: Oslo Nye Teater, Nationaltheatret, Den Nationale Scene, Teatret Vårt, Trøndelag Teater, Sogn og Fjordane Teater.

11 Skyggearkiv kan være materiale som mangler i arkivet eller materiale som er samlet inn, men som ikke er tilgjengelig. Det siste kan være fordi materialet ikke er registrert i arkivet ennå eller det kan grunne i opphavsrettslige problemstillinger. Det første kalles backlog og grunner i at kapasitet/ressurser er mindre enn behov/etterspørsel. Ligger arkivet i backlog er det bevart, men venter på ordning, registrering og tilgjengeliggjøring. Materialet som ikke kan tilgjengeliggjøres grunnet opphavsrett, er semitilgjengelig via publisering av metadataene knyttet til dokumentet. Slik kan brukeren få informasjon om hva slags materiale det er snakk om og hvor det er å finne. Skyggearkivene er altså ikke nødvendigvis det samme som mangler $\mathrm{i}$ arkivene.

12 Røssak, Archives in motion.

${ }^{13}$ Rasmussen, "Devices of Memory and Forgetting: A Media-Centred Perspective on the "Present Past"”, 109-126.

14 NOU 2013.

${ }^{15}$ MARC - Machine-Readable Cataloguing er en standard digital bibliotekkatalog som blir brukt av de fleste bibliotek i Norge. MARC ble utviklet på 1970-tallet og erstattet med tiden de fysiske kortkatalogene AACR - Anglo American Cataloguing Rules. CIDOC CRM - Conceptual Reference Model ble utviklet på tidlig 200-tallet og er en konseptuell databasemodell som er utviklet for katalogisering av museumssamlingers fysiske objekter og arkivdokumenter. FRBR - Functional Requirements for Bibliographic Records er en konseptuell objektbasert og relasjonell databasemodell som ble startet utviklet 
på slutten av 1990-tallet av International Federation of Library Associations. Primus er en database utviklet av ABM-utvikling for registrering av fotografier.

${ }^{16}$ Nordlie, «Kunnskapsorganisasjon - "kjerneteknologi" for bibliotek- og informasjonsfag», 6-16, 7.

${ }^{17}$ Nordlie, «Kunnskapsorganisasjon - "kjerneteknologi” for bibliotek- og informasjonsfag», 6-16.

18 Ibid.

${ }^{19}$ Ibid.

${ }^{20}$ Aalstad, Kunnskapsorganisering.

${ }^{21}$ Nordlie, «Kunnskapsorganisasjon - "kjerneteknologi” for bibliotek- og informasjonsfag», 6-16.

22 Ibid.

${ }^{23}$ Rasmussen, "Devices of Memory and Forgetting: A Media-Centred Perspective on the "Present Past"', $109-126$.

${ }^{24}$ Når man skal tilgjengliggjøre materiale, må man forholde seg til regelverk om publisering og personvern. En betydelig del av arbeidet med Scenewebdatabasen dreier seg nettopp rundt opphavsrettslige problemstillinger. Det må identifiseres hvem som har opphavsrett til materialet og inngås avtaler med disse angående lisenser og muligheter for publisering. Vi er også forpliktet til å følge den norske personvernloven og EUs personvernregler når det gjelder publisering av materiale med bilder og video av mennesker og materiale som skriftlig omhandler individer.

${ }^{25}$ Derrida, Archive fever.

${ }^{26}$ Ibid, 33-36. 


\section{Bibliografi}

Connerton, Paul. How societies remember. Cambridge: Cambridge University Press, 1989.

Convention for the Safeguarding of the Intangible Cultural Heritage 2003. Fastsatt ved the General Conference of the United Nations Educational, Scientific and Cultural Organization (UNESCO) 17. oktober 2003. 28.05.2019. http://portal.unesco.org/en/ev.phpURL ID=17716\&URL DO=DO TOPIC\&URL SECTION=201.html

Derrida, Jaques. Archive fever. Chicago \& London: The University of Chicago Press, 1998.

Halbwachs, Maurice. The collective memory. New York: Harper \& Row, 1980.

Jakobsen, Kjetil: “Anarchival Society”. The Archive in Motion. Oslo, Nasjonalbiblioteket, 2010.

Jones, Caitlin, and Lizzie Muller. Between Real and Ideal: Documenting Media Art. Leonardo. Project Muse 41 (4) (2008): 418-419.

Kultur- og kirkedepartementet. «Nasjonal strategi for bevaring av og formidling av kulturarv». St.meld.nr. 24 (2008-2009). Oslo: Kultur- og kirkedepartementet, 2009. 17.04.2009. https://www.regjeringen.no/no/dokumenter/stmeld-nr-24-2008-2009-/id555254/

Kulturrådet. Immateriell kulturarv i Norge. En utredning om UNESCO konvensjonen av 17. Oktober 2003 om vern av den immaterielle kulturarven. Oslo: Kulturrådet, 2010. https://issuu.com/norsk kulturrad/docs/rapport immatriell kulturarv web/12

Luhmann, Niklas. Sociale systemer. København, Hans Reitzels forlag, 2000.

Nordlie, Ragnar. «Kunnskapsorganisasjon - "kjerneteknologi" for bibliotek- og informasjonsfag». Kunnskapsorganisering. Bibliotheca Nova nr. 4 - 2014. Oslo, Nasjonalbiblioteket, 2014.

NOU 2013: 4. Kulturutredningen 2014. Oslo: Kulturdepartementet, 2013. https://www.regjeringen.no/no/dokumenter/nou-2013-4/id715404/

Pliktavleveringslova. Lov om avlevereingspliket for allment tilgjengelege dokument m.v. av 9. juni 1989 nr. 32. 14.05.2018. https://lovdata.no/dokument/NL/lov/1989-06-09-32

Rasmussen, Terje. «Devices of Memory and Forgetting: A Media-Centred Perspective on the "Present Past"». The Archive in Motion. Oslo, Nasjonalbiblioteket, 2010.

Rasmussen, Terje. Lubmann: Kommunikasjon, medier, samfunn. Bergen, Fagbokforlaget, 2003.

Røssak, Eivind (red). Archives in motion. Nota Bene. Oslo, Nasjonalbiblioteket, 2010.

Store Norske Leksikon, snl.no

Vestli, Håkon Bjørge. Norwegian Repertoire Databases for Performing Arts - What and Why. Masteroppgave. Høgskolen i Oslo (nå: OsloMET), 2007.

Aalstad, Gunhild H. (red.). Kunnskapsorganisering. Bibliotheca Nova nr. 4 - 2014. Oslo, Nasjonalbiblioteket, 2014. 